\title{
Paideusis
}

\section{Editorial Introduction to Special Themed Issue: Contemplative Practice, Education, and Socio-Political Transformation (Part Two)}

\section{Claudia Eppert and Daniel Vokey}

Volume 21, Number 1, 2013

Contemplative Practice, Education, and Socio-Political

Transformation (Part Two)

URI: https://id.erudit.org/iderudit/1071569ar

DOI: https://doi.org/10.7202/1071569ar

See table of contents

Publisher(s)

Canadian Philosophy of Education Society

ISSN

0838-4517 (print)

1916-0348 (digital)

Explore this journal

Cite this document

Eppert, C. \& Vokey, D. (2013). Editorial Introduction to Special Themed Issue:

Contemplative Practice, Education, and Socio-Political Transformation (Part

Two). Paideusis, 21(1), 1-3. https://doi.org/10.7202/1071569ar

This document is protected by copyright law. Use of the services of Erudit (including reproduction) is subject to its terms and conditions, which can be viewed online.

https://apropos.erudit.org/en/users/policy-on-use/ 
Paideusis, Volume 21 (2013), No. 1, pp. 1-3

\title{
Editorial Introduction to Special Themed Issue: Contemplative Practice, Education, and Socio- Political Transformation (Part Two)
}

\author{
CLAUDIA EPPERT AND DANIEL VOKEY \\ University of Alberta and University of British Columbia
}

We are delighted to introduce the second of our two special themed issues on Contemplative Practice, Education, and Socio-Political Transformation. In addition to the articles on its focus topic, this issue includes an open topic article, two responses in its Dialogue Section, and a book review. As mentioned in our previous editorial introduction, we arrived at our special theme in response to the marked rise of interest in contemplative studies both inside and outside educational discourses in recent years. Specifically, we wanted to create space for philosophical reflection and dialogue on the potential for contemplative practices to promote more just, compassionate, and sustainable ways of life. Contemplative practices are increasingly recognized for their capacities to enhance individual well-being. But what can be said about the complex connections between personal well-being and communal, collective, and global transformation toward social and environmental justice? Do engagements with contemplative practices yield insights into the proper aims and means of social and environmental justice education? How, if at all, can the field of contemplative studies bring us to deeper awareness and appreciation of our interdependence with aspects of ourselves, with each other, and with our environment and cosmos? It is easy to assert that, within an interdependent worldview, the well-being of self, other, and planet are integrally connected. But how can we conceive of and enact interdependence more deeply and fully? And in what measure might educational theory, policies and practices become more embedded within senses of interdependent well-being, responsiveness, and responsibility?

The three articles that comprise the special thematic section of this issue take up these concerns. They envision alternatives through an embrace of different wisdom traditions, at once seeking both to show respect for the histories and cultures in which these traditions are embedded and to identify possibilities of learning from and re-engaging contemplative practices in ways that might speak to changing and diverse contemporary contexts. From the perspective of their traditions, each author addresses the following questions:

- What specific struggles are schools, education, and societies encountering today?

- How do particular contemplative philosophies and practices shed light on and challenge contemporary paradigms and struggles?

- What educational alternatives are introduced through these philosophies and practices that might facilitate personal and social transformation?

In his "Descartes in a 'Headstand': Introducing Body-Oriented Pedagogy," Oren Ergas attends to the limitations of the Cartesian mind-body dualism that has informed much of modern Western education. He critiques French philosopher René Descartes' (1596-1650) disavowal of the senses and emotion as legitimate sources of knowledge and engagement. Ergas intends to subvert the Cartesian worldview through a

(C) Copyright 2013. The authors, Claudia Eppert \& Daniel Vokey, assign to Paideusis the right of first publication and educational and non-profit institutions a non-exclusive license to use this document for personal use and in courses of instruction provided that the article is used in full and this copyright statement is reproduced. Any other usage is probibited without the express permission of the author. 
discussion of classical yoga, which emphasizes a contrasting mind-body relationship. He subsequently illustrates how classical yoga philosophy and practice introduce the importance of what he calls a "bodyoriented pedagogy," with the potential to revitalize educational and public spheres.

In her "Goddess Puja in California: Embodying Contemplation through Women's Spirituality," Nané Jordan questions conventional Western academic and medical practices, which she maintains can benefit from a more holistic and whole-bodied engagements. Moreover, she highlights how Western culture has emphasized a hyper-consumer view of the female body, and woman-centered spiritual leadership remains largely absent or invisible. Inspired by her experiences as a lay midwife and as a student in a unique Women's Spirituality Master of Arts (WSMA) degree program in California, she illustrates the value of reclaiming female symbolism, spiritual expression, and women and earth-centered experience and divinity. She details how gender and eco-social justice are enhanced by such contemplative experience and expression. Of specific interest is the ancient Indian and transcultural ritual of Goddess puja or worship. In mindful and poetic language, she narratives how such a ritual has the potential to heal and re-infuse life into contemporary institutions and culture.

Finally, in her article, “Towards Skillful Global Citizenship Education,” Tram Truong Anh Nguyen questions how international social action initiatives are engaged within the context of global citizenship education. She expresses particular concern about 'helping practices' that threaten to reproduce rather than transform societal inequalities. In order to draw attention to the problems here and also to point the way to alternatives, she draws upon the Buddhist writings of Thich Nhat Hanh. Specifically, she introduces Buddhist conceptions of suffering, no-self, and the law of karma, and considers how these deepen our understanding of human nature and possibility. She subsequently recommends a "skillful" approach to global citizenship education, consisting of a skillful awareness of interdependence, skillful compassion, and skillful awareness of intention.

The Open Article Section of this issue features Benjamin Hamby's "Libri ad Nauseam: The Critical Thinking Textbook Glut," in which he details his critique of textbooks that purport to teach critical thinking. He emphasizes that teaching critical thinking extends beyond teaching argument analysis and evaluation, and includes cultivating capacities, for example, to question assumptions, to attend to the neglect of alternative perspectives, and to recognize emotionally charged language. Hamby also introduces readers to some important criteria that may help critical thinking instructors and authors judge and choose their textbooks.

The Dialogue Section, which invites authors to respond to content in previous issues or initiate new discussions, contains two pieces. In the first, titled "Environmental Education, Student Autonomy, and the Non-Idolization of Science," David P. Burns and Stephen P. Norris offer a reply to a reflection written by Blair Niblett (2012) in response to their original Paideusis article (2009) titled "Open-Minded Environmental Education in the Science Classroom." In their reply, the authors contend that, while they do not encourage the championing of specific activist environmental agendas and causes in the science classroom, they do support teachers encouraging students to critically engage social questions and consider diverse perspectives and positions on an issue.

The second piece, by Fred Harris, offers a Deweyan critique of Thomas Falkenberg's (2012) article, titled "Teaching as Professional Contemplative Practice." Harris draws upon the writings of John Dewey in order to question aspects of Falkenberg's discussion on mindfulness meditation. Harris recommends that this contemplative practice alone is insufficient if it does not critique the modern curriculum and the suffering students experience in being required to participate in this curriculum.

Finally, this issue also includes a book review by Clarence W. Joldersma of Chris Higgins' recently published book, The Good Life of Teaching: An Ethics of Professional Practice. This review nicely complements the special theme of this issue as it brings attention to the intrinsic goodness of teaching and the importance of educators practicing senses of responsibility that include taking into account governing social inequities and educators cultivating self-care and personal well-being. In other words, in order to be fully available to others, teachers must insure their own flourishing.

We hope you enjoy this issue as much as the last. As mentioned previously, should you be interested in writing responses, or seek to be included in our database as a potential reviewer, please do not hesitate to contact us. Please stay tuned for our Fall 2013 volume, which will feature the special theme of "Working Compassion," guest edited by Heesoon Bai. Contributors will be participants from the March 2012 academic 
symposium that Heesoon organized with the help and support from her colleagues, graduate students, and the Center for Dialogue at Simon Fraser University. This special theme was inspired by Karen Armstrong's "Charter for Compassion" initiative.

For this issue, we wish to extend our appreciation to Jim Bigari, our copy-editor, for his continued diligence, knowledge, and insight. Our thanks also to Kevin Stranack for his stellar technological assistance, and to David Waddington for his hard work as Paideusis Book Review Editor. We continue to be appreciative of Editorial Board Members Ann Chinnery (Secretary Treasurer), Doug Simpson (President of the Canadian Philosophy of Education Society, CPES), and Michelle Forrest (Past President of CPES). A deep bow of thanks to the reviewers of our many submissions over these last months-we are ever grateful for their constructive feedback. Finally, on behalf of CPES, we wish to acknowledge with appreciation the financial support for Paideusis received from the Department of Educational Studies and from the Office of Graduate Programs and Research, both units within the Faculty of Education of the University of British Columbia. 